\title{
THE PERMANENT COURT OF JUSTICE AND THE GERMAN MINORITY IN POLAND (1923-1934)
}

\author{
(1) http://orcid.org/0000-0002-6405-5380
}

\section{Giuseppe Motta}

Sapienza University of Rome

\begin{abstract}
This study examines decisions of the Permanent Court of International Justice and their impact on the German-Polish dispute. It considers how international jurisdiction approached the question of minority protection and how the efficiency of this experiment in international justice was extremely influenced by political motives and contrasting political visions. The fragile balance between legal and political aspects was evident, and despite the efforts of the Court, political interests prevailed. It will be argued that the problems of the minority system and the German-Polish controversies proved that the international institutions could only provide the states with a support in settling their disputes: international stability could only be guaranteed by sincere mutual cooperation among the members of a community of states.
\end{abstract}

Keywords: minority protection, Permanent Court of International Justice, League of Nations, German-Polish relations.

After World War I, Poland went back to being one of the most extended States of Central-Eastern Europe and annexed many regions with substantial minorities. The creation of the Polish Corridor, the stipulation of the Polish minority treaty (1919), the question of Danzig, the plebiscites of Allenstein, Marienwerder (1920) and Upper Silesia (1921) reflected the great complexity of the German-Polish relations, which became one of the most important international issues of the interwar period.

The new political settlement included the special minority treaties that Poland, Czechoslovakia, Romania, the Kingdom of Serbs, Croats and Slovenes and Greece were encouraged to sign in 1919-20, promising their citizens perfect equality, in law and in fact, with no regard to race, religion and language. Though the protection of minorities was put under the jurisdiction of the League of Nations, and Germany was not a member, Ignacy Paderewski explicitly criticized this protection by foreign powers, interpreting it as a political humiliation and an infringement of Polish national sovereignty. Polish criticism was justified by the lack of a general obligation upon 
all the members of the League, which permitted Germany, well before the admission into the League in 1926, to use the minority system without being subjected to.

The German minority in Poland was not numerically substantial (769,392 Germans in 1921 and 741,000 Germans in 1931, representing respectively $2.99 \%$ and $2.3 \%$ of the total population), but had a well consolidated social and economic position especially in the Western provinces they were principally residing in (Poznan, Pomerania, Silesia and Łódź). ${ }^{1}$ These provinces were of great economic significance: Poznańskie Voivodeship, for example, was one of the richest with a highly efficient agriculture, while Silesia, with its rich deposits of coal, was the industrial center of the country and was crucial to Polish armaments production.

As Richard Blanke remarked, the new situation meant a radical transformation: a Polish government confronted a small but powerful German minority in regions where power relationships had long been the other way around. The former dominant groups became the new minorities, while the previously dominated groups had the opportunity to repay past injustice. ${ }^{2}$ On the one hand, many Germans regarded Poland as a temporary State, an abomination, while Poles were generally seen as less civilized people, childlike, primitive and savage. ${ }^{3}$ On the other, the violence of the past exacerbated the will of social revanche of non-German people conceiving their new National State as the perfect means to create a new society, free from the feudal privileges of the past.

This dualism is well evident in both national historiographies, which emphasized the anti-Polish posture of the German leaders and similar declarations of Polish politicians. ${ }^{4}$ Furthermore, many works reflected upon the nature, sincere or instrumen-

${ }^{1}$ P. Eberhardt, Ethnic Groups and Population Changes in Twentieth Century Central-Eastern Europe: History, Data, and Analysis, Armonk-London 2003, pp. 113-115. See in detail: E. Romer, The Population of Poland according to the Census of 1921, "Geographical Review" 1923, vol. 13(3), pp. 398-412; J. Tomaszewski, Rzeczpospolita wielu narodów, Warszawa 1985; W. Roszkowski, Landowners in Poland, 1918-1939, London 1991.

${ }^{2}$ R. Blanke, "When Germans and Poles Lived Together: From the History of German-Polish Relations" [in:] Germany and Eastern Europe, Cultural Identities and Cultural Differences, eds. K. Bullivant, G. Giles, W. Pape, Amsterdam-Atlanta 1999, p. 47.

${ }^{3}$ J. Lieskounig, "Branntweintrinkende Wilde. Beyond Civilization and Outside History: The Depiction of the Poles in Gustav Freytag's 'Soll und Haben"' [in:] Germany and Eastern Europe: Cultural Identities and Cultural Differences, eds. K. Bullivant, G. Giles, W. Pape, AmsterdamAtlanta 1999, p. 138.

${ }^{4}$ On one side, Irredentism and Provocation: A Contribution to the History of German Minority in Poland, ed. A. Lesniewski, Poznań 1960; J. Krasuski, Stosunki polsko-niemieckie 1919-1932, Poznań 1975; Z. Dworecki, Problem niemiecki w świadomości narodowo-politycznej spoleczeństwa polskiego województw zachodnich Rzeczypospolitej, 1922-39, Poznań 1981; H. Chałup czak, "Poland's Strategy to Neutralize the German Minority's Petitions at the League of Nations in the Interwar Period," Polityka i Spoleczeństwo 2012, vol. 9, pp. 16-26; T. Land mann, "The Impact of Ukrainian and German Minorities in Poland on the Security of the State in the Years 1919-1939," Journal of Science of the Gen. Tadeusz Kosiuszko Military Academy of Land Forces 2016, vol. 48, no. 3, pp. 52-70; P.D. S ta c hur a, Poland 1918-1945. An Interpretative and Documentary History of the Second Republic, London-New York 2004; Poland between the Wars, 1918-1939, ed. P.D. Stachura, London 1998. On the other, C. Gütermann, Das Minderheitenschutzverfahren des Völkerbundes, Berlin 1979; B. Schot, Nation oder Staat? Deutschland und der Minderheitsschutz zur Völkerbundspolitik d. Stresemann-Ära, Marburg 
tal, of German foreign policy before and after the rise of Nazism and the consideration of the German minority as a "Fifth Column" or Himmler's Auxiliaries of German revisionism. ${ }^{5}$ An important consequence of this national-addressed vision of German-Polish relations is what Winston Chu defined as the minority's victimization in the terms of a Manichean Volkstumskampf, which equated minority politics with the conflict between German leaders and Polish authorities. ${ }^{6}$ Besides the vision of interethnic relations as a challenge towards extermination or ethnic cleansing, after 1989 scholarship changed perspectives and replaced the reciprocal image of majority-minority as homogeneous inimical rivals with that of heterogeneous communities with internal dynamics and conflicts. This aspect has been widely illustrated in several numbers of the review Nordost-Archiv and represents one of the factors that leads Dariusz Matelski to substantially absolve the German minority from the accusation of being Germany's "Fifth Column."

The aim of this article, however, is not to analyze anew either the rights and wrongs of opposite national visions or the local conditions of the Germans in Poland, but the international impact of this intricated issue, offering a new perspective thanks to the documents of the Permanent Court of International Justice. These illustrate the rare public side of the League's minority system and are helpful to better understand not only the legal aspects of many disputes that animated German-Polish relations, but the overall approach and the subsequent difficulties of the newly created international institutions. ${ }^{8}$ The relationships between Germany and Poland were conditioned by a fragile balance between political dynamics and judicial aspects, between official pacification and subterranean tensions, the formal respect of treaties and the minority-majority dynamics internal to many States. Under this perspective, the legal nature of the documents intersects with their political impact and represents an interesting field of study, not only to discuss some specific aspects of the German-Polish controversies in their legal dimension, but also to analyze the divide between the technicalities of international law and the problematic nature of interethnic tensions

1988; S. Z1och, Polnischer Nationalismus, Politik unde Gesellschaft zwischen den beiden Weltkriegen, Koln-Weimar-Wien 2010.

${ }^{5}$ On German foreign policy, B. Schot, Stresemann der deutsche Osten und der Völkerbund, Wiesbaden-Stuttgart 1984; R. Blanke, "The German Minority in Inter-War Poland and German Foreign Policy - Some Reconsiderations," Journal of Contemporary History 1990, vol. 25, no. 1, pp. 87-102; idem, Orphans of Versailles: The Germans in Western Poland, 1918-1939, Lexington 1993; C. Raitz von Frentz, A lesson forgotten: minority protection under the League of Nations: The Case of the German Minority in Poland, 1920-1934, New York 1999; L.O. Valdis, Himmler's Auxiliaries: the Volkdeutsche Mittelstell and the German National Minorities of Europe, 1933-1945, Chapel Hill 1993.

6 W. Chu, The German Minority in Interwar Poland, New York 2012, p. 9.

${ }^{7}$ D. Matelski, Niemcy w Polsce w XX wieku, Warszawa-Poznań 1999, pp. 41-48, 331-334; D. Matelski, Niemcy w II Rzeczypospolitej (1918-1939), 2 vols, Toruń 2018. "Nordost-Archiv," VI (1997), 2: Formen kollektiver Identität in einer deutsch-polnischen Region; Nordost-Archiv, IX (200), 2: Die Erforschung der Geschichte der Deutschen in Polen. Stand und Zukunftsperspektiven. See also, P. Blachetta-Madajczyk, Klassenkampf oder Nation? Deutsche Sozialdemokratie in Polen 19181939, Düsseldorf 1997.

${ }^{8}$ German petitions against Poland represented $26,8 \%$ of the protests sent to the League: only $7 \%$ was finally settled by international institutions. D. Matelski, Niemcy w Polsce w XX wieku, p. 60. 
in the local context. The German-Polish case study could thus prove very significative in understanding the fragility of this complex international system in the phase of implementation, and the inherent contradictions between judicial considerations and political dynamics.

\section{THE BEGINNING OF THE POLISH-GERMAN CONTROVERSY}

After the Wielkopolska uprising (1918-19), the conditions of German minorities in Poland and, in particular the question of German estates, became the most common theme under the attention of international institutions. ${ }^{9}$ During previous decades, German presence in Polish territories had been strengthened by the Prussian Settlement Commission, which was established in 1886, in a context that Róisín Healy and David Blackbourn described as a colonial process. ${ }^{10}$ During the negotiations at Versailles, Polish publications described this artificial Germanization as a policy of extermination of Polish presence in the provinces of Prussia and Poznan. ${ }^{11}$ It was natural, therefore, that the new Polish State aimed to cancel the effects of this colonization process, which had meant the increase of German properties, functionaries and officials.

With almost the half of the total area of Poland in the hands of huge landowners, the agrarian question was an extremely sensitive socio-economic problem and clearly affected the relations of the German minority in the western provinces. Polish measures aimed to the re-distribution of the means of production, and in many regions agrarian reforms were an instrument to appease peasantry, dispossess alien landlords and cement the economic framework of new national boundaries. The minorities, on the contrary, claimed that the measures were expressly directed against them, as the application of the reform contained differences in the Eastern and Western provinces, and the local land offices had great powers of implementation. ${ }^{12}$

${ }^{9}$ A. Spiliopoulou Åkermark, Justifications of Minority Protection in International Law, London-The Hague-Boston 1997, p. 109.

${ }^{10}$ R. Healy, "From Commonwealth to Colony? Poland under Prussia" [in:] The Shadow of Colonialism on Europeis Modern Past, eds. R. Healy, E. Dal Lago, New York 2014, pp. 109-125; D. Blackbourn, "Das Kaiserreich transnational" [in:] Das Kaiserreich transnational: Deutschland in der Welt, 1871-1914, eds. S. Conrad, J. Oster hamme1, Göttingen 2004, p. 322; W. Hag en, Germans, Poles, and Jews: The Nationality Conflict in the Prussian East, 1772-1914, Chicago 1980.

${ }^{11}$ See for example the booklets printed in Paris in 1919, Système Prussien d'extermination dans les Provinces Polonaise; Population allemande en dépendance directe du Gouvernment Prussien. K. Lundgren-Niels en, The Polish Problem at the Paris Peace Conference: A Study of the Policies of the Great Powers and the Poles, 1918-1919, Odense 1979.

${ }_{12}$ M. Błąd, "Land Reform in the Second Polish Republic," Rural History 2000, vol. 31 (1), pp. 97-110. See also: Z. Ludkiewicz, "Land Reform in Poland," The Slavonic and East European Review 1929, vol. 8, no. 23, pp. 322-323; D.T. Pronin, "Land Reform in Poland, 1920-1945," Land Economics 1949, vol. 25, no. 2, pp. 133-143. 
As a consequence, the agrarian policies of the Polish republic gave birth to harsh international controversies. The first one was caused by the fact that, after the armistice, German colonization authorities finalized certain contracts that had been signed with German colonists before November 11, 1918. The Polish government argued that Germany was trying to convert all public properties into private ones, in order to avoid the effect of Polish laws, which nullified all post-armistice transactions of German properties and leases. Many German settlers had their property rights challenged, as they had signed a valid contract but had not inscribed their title (Auflassung) into the official property register before November 1918.

On November 8, 1921, the German League for the Protection of the Rights of Minorities in Poland protested against the expropriations. Poland rebutted the charges, and Germany launched a press campaign against Warsaw's "politics of extermination." 13 The question was analysed by a Committee of the League that issued a preliminary report on January 23, 1922, advising the Polish government to suspend all measures that might in any way affect the settlers, and to send its observations to the Council. ${ }^{14}$ On May 17, 1922, the Council repeated its warnings, while the Polish government rendered further information during an extraordinary session of the Council, in July 1922, when a special committee of jurists was appointed. After a careful study, this committee concluded that the Polish measures were in contrast with the treaties, and that the expulsion of settlers was not justified, not even in the mentioned cases when the contracts were valid, but property rights had not been entered into the official register before November 1918. Various circumstances, including the delay in fixing the boundaries and the natural consequences of war, were such as to excuse the non-completion of the transfer, and the settlers should thus be left in possession of their lands.

The Polish government questioned the soundness of these conclusions, and on February 3, 1923, the Council members almost unanimously decided to require an advisory opinion to the Permanent Court of Justice. ${ }^{15}$ In this advisory opinion, the Court first considered the question of jurisdiction, then entered into the merits of the dispute. The magistrates considered that the lack of any reference to race in the text of the Polish law of July 14, 1920, did not mean that it automatically guaranteed equality in fact. ${ }^{16}$ The tribunal explained that even without mentioning the race of the persons who were to be ousted, the inference that they were German was to be drawn from the clauses of the law. It was undoubtedly true that those persons had been settled upon the lands in pursuance of a policy of Germanization, but the Court pondered that the effects of the law of July 14, 1920, were inevitably to result in a similar policy of discriminatory de-Germanization. Naturally, such a measure

13 C. Raitz von Frentz, A Lesson Forgotten, p. 214. A. Sammartino, The Impossible Border, Germany and the East, 1914-1922, Ithaca 2010, pp. 115-119.

14 Historical Archives of the League of Nations (Haln), League of Nations Secretariat, 1919-1946, section 41, box R1661, dossier 12865.

15 Official Journal of the League of Nations (Ojln) 1923, 7, p. 717.

${ }^{16}$ Questions Relating to Settlers of German Origin in Poland (Advisory Opinion, Sept. 10, 1923), "Publications of the Permanent Court of International Justice," series B, 6, Leyden 1923. 
might be comprehensible and justified by the past campaign of German colonization and by the improvised finalization of the transfer but was in contrast with the norms of private law and the principle of succession of States. Equality before the law (de jure), the Court explained, did not always coincide with equality in fact (de facto).

The Court pointed out that the omission of registration could not affect the rights of the settlers, who acquired a right to the land (jus ad rem) even before inscribing the Auflassung into the register. The political motive of those contracts was clearly understandable but was not relevant for the Court: Polish treasury could only replace the Prussian State in the land register. Furthermore, the Council suggested full compensation for the losses that the colonists suffered as a result of the fact they had not been left undisturbed possession of such properties. ${ }^{17}$

The opinion of the Court was followed by a new phase of bilateral negotiations for a Polish-German agreement, which was formally approved by the Council in September 1924. But the calm was just apparent. In 1922-24 the Polish government launched a press campaign against its "disloyal minority." The Deutschtumsbund and other private German organizations were dissolved due to their subversive relations with a foreign power, and the petitions to the League were presented as a proof of disloyalty. ${ }^{18}$

In those years, two important political events conditioned the status of GermanPolish relations: the customs war and the conclusion of a Western security pact with Germany. Germany's recognition of crucial security guarantees vis-à-vis the longtime rival France constituted a novelty in post-war foreign policy, but the security in the West created vivid anxiety in the East. The agreement of Locarno formally guaranteed the frontiers with France and Belgium, while on the other side the arbitration treaty between Poland and Germany (October 16, 1925) excluded territorial questions and merely referred to a permanent conciliation commission, or to the Permanent Court of Justice. According to Gustav Stresemann, the Locarno treaties were an armistice that was valid only in the West. ${ }^{19}$

The situation was interpreted by Polish politicians as if there were first and secondclass frontiers. Józef Piłsudski and August Zaleski, future minister of foreign affairs, as well as the Polish General Staff were very critical and this widespread discontent contributed to the fall of Władysław Grabski's cabinet and, a few months later, to the May Coup that consecrated Piłsudski's rise to power and the start of Sanacja regime.

The implicit possibility of revisionism stemming from Locarno caused deterioration of the Polish-German relations and had negative repercussions on the position of the German minority. On the other side, the agreements of Locarno were followed by the admission of Germany into the League of Nations, in 1926. In the context that Gregor Thum defined as a "völkisch turn," this new status in the international sce-

${ }^{17}$ Ibidem, pars. 38, 40, 95. Conclusions of the Ninth Meeting, Twenty-Seventh Session of the Council, December 17, 1923. Ojln, 1924, 2, p. 359.

${ }^{18}$ C. Fink, "Minority Rights as an International Question," Contemporary European History 2000, vol. 9 , no. 3 , pp. $390 \mathrm{ff}$.

${ }_{19}$ A.M. Cienciala, T. Komarnicki, From Versailles to Locarno, Keys to Polish Foreign Policy 1919-1925, Lawrence, Kan. 1984, pp. 239-241, 273. 
nario permitted Berlin to play the role of champion of minority rights, as the minority issues could be instrumental to present Germany as a supporter of Wilsonianism and to strengthen the sense of political unity within and outside the Weimar system. ${ }^{20}$ After the admission, thanks to the inflow of financial resources from different Auslandsdeutsche organizations in Germany, an enormous amount of propaganda manifestations and petitions affected Poland, which fell victim of the German intricate and controversial Minderheitenpolitik that Carole Fink portrayed as "a combination of revisionist hopes, völkisch arrogance, and humanitarian concern for the fate of lost kin.. ${ }^{21}$

\section{THE COURT AND UPPER SILESIA}

Upper Silesia played a special role in German-Polish relations and one of the first controversies that arouse after Germany's admission in the League concerned just the expropriation of some large agricultural estates in the region. Upper Silesia had experienced a troublesome transition through a plebiscite (March 20,1921), three uprisings (the last in May 1921), and the final partition in October 1921, which granted Poland a substantial part of the area and its industry. Things were further complicated by the ethnic complexity of the region, which well adapts to the concept of national indifference that recent scholarship has extensively analysed (James E. Bjork, Pieter Judson, Jeremy King, Tara Zahra). As argued by Andrew Demshuk, in Silesia national identity remained ambiguous: people were neither Germans nor Poles, and many bilingual Poles, the so-called Wasser Polen (watered Poles), had fully adapted to the social and economic conditions under Prussian rule. ${ }^{22}$

A regional regime was established through the concession of a special autonomy status including a regional Sejm, while the convention of Geneva (May 15, 1922) regulated in detail the protection of respective minorities with special procedures and mixed tribunals. But this well-defined legal structure did not prevent the region from being at the heart of bitter controversies. As remarked by Tomasz Kamusella, revisionism and non-acceptance of the existing border between Poland and Germany was widespread in Upper Silesia, which became a ground of contest between German

${ }^{20}$ G. Thum, "Mythische Landschaften. Das Bild vom deutschen Osten und die Zäsuren des 20. Jahrhunderts" [in:] Traumland Osten. Deutsche Bilder vom östlichen Europa im 20. Jahrhundert, ed. G. Thum, Göttingern 2006; C. Fink, "Stresemann's Minority Policies, 1924-29," Journal of Contemporary History 1979, vol. 14, no. 3, pp. 407-408; J. Wright, Gustav Stresemann. Weimar's Greatest Statesman, New York-Oxford 2002, p. 466.

${ }^{21}$ C. Fink, "Defender of Minorities: Germany in the League of Nations, 1926-1933," Central European History 1972, vol. 5, pp. 330-357; E. Wy not, “The Polish Germans, 1919-39," Polish Review 1972, vol. 17, pp. 23-64.

22 A. Dem shuk, The Lost German East: Forced Migration and the Politics of Memory, 1945-1970, New York 2012p. 43; T. Kamu sella, The Dynamics of the Policies of Ethnic Cleansing in Silesia in the Nineteenth and Twentieth Centuries, Budapest 1999, pp. 372-3. See also, T. Hunt Tooley, National Identity and Weimar Germany: Upper Silesia and the Eastern Border, Lincoln-London 1997. 
and Polish nationalisms. On the one side, Germany renewed Germanizing efforts in the Oppeln Regency, on the other the appointment of Michał Grażyński as voivode in 1926 reduced Silesian autonomy and intensified de-Germanization measures in the economic and cultural fields. ${ }^{23}$

German entrepreneurship had a consolidated position in the economic fabric of the region and was clearly affected by the policies of the Polish State, which was targeted at reducing this presence. The Polish agrarian reform, in particular, generated a potential conflict with Head III of the Geneva Convention, which limited the liquidations of German nationals. After the decisions of a civil court at Katowice, and of the German-Polish Mixed Arbitral Tribunal at Paris, the appeal of some German owners was first discussed in the Council of the League and then brought before the Permanent Court of International Justice by the German application of May 15, 1925. On June 22, 24 and 25, the court affirmed its jurisdiction and reserved the suit for judgment on the merits.

The Court decided to give special attention to the analysis of the Chorzów nitrate factory's expropriation. The question concerned the public or private nature of this factory, which had been ceded by the German State to two different companies: the Bayerische Stickstoffwerke and Oberschlesische Stickstoffwerke. On January 29, 1920, the Oberschlesische Stickstoffwerke was duly entered in the Chorzów land register as the owner of the nitrate factory. But on July 1, 1922, the Polish tribunals decided that the registration in question was null and void and was to be cancelled: the factory of Chorzów was still to be regarded as a public company, and on July 3, 1922 the property rights were transferred to the Polish treasury.

Oberschlesische and Bayerische companies protested against the deletion of their rights and their case was associated with the analogous position of other twelve owners of large agricultural estates, who all reacted against the expropriation of their properties..$^{24}$ After the discussion in the Council, in 1926, the Court drafted a preliminary judgment dismissing the pleas of the Polish government against its jurisdiction, and on March 22, 1926, issued an order inviting the parties to supply all necessary documents. ${ }^{25}$

The merits were analysed in another verdict, which condemned the fact that Poland regarded as null and non-existing the rights that private persons might have acquired after November 1918: "the alienation was a genuine transaction effected in good faith and was not designed to be detrimental to Poland's rights." The Oberschlesische's ownership should be regarded as established and could not be affected by Polish laws of 1920 and 1922, as the expropriation without compensation was contrary to Head III (articles 6-22) of the Geneva Convention. ${ }^{26}$

${ }^{23}$ T. Kamuse1la, The Dynamics of the Policies of Ethnic Cleansing, pp. 375-376.

${ }^{24}$ Case concerning certain German interests in Polish Upper Silesia (Judgment, May 25, 1926), Publications of the Permanent Court of International Justice, series A, 7, Leyden 1926.

${ }_{25}$ German Interests in Polish Upper Silesia (Order, March 22, 1925), Publications of the Permanent Court of International Justice, series A, 6-7, Leyden 1925.

${ }^{26}$ Case Concerning the Factory at Chorzów (Claim for Indemnity, July 26, 1927), Publications of the Permanent Court of International Justice, series A, 9, Leyden 1927. 
In the other cases of expropriation, the Court elaborated many individual statements, generally in favour of German applicants: their properties were once and for all immune from any possible expropriation and the appeals were well-founded. ${ }^{27}$ Only in a few cases, the tribunal sentenced that the applications had to be dismissed for lack of sufficiently substantiated statements (case of Prince of Hohenlohe-Oehringen), or because the applicants had not set their domicile in Upper Silesia (cases of Duke of Ratibor and Count Saurma-Jeltsch). The decision did not satisfy the Polish government, and the Polish representative, Count Rostworowski, entered his protest in the minutes of the judgement. ${ }^{28}$

The dispute continued as Berlin decided to ask for the payment of some indemnities for the illegal possession and exploitation of the Chorzów factory. The judges once again dismissed the Polish pleas about jurisdiction, and the Polish delegate Ludwik Ehrlich expressed his disappointment for the judgement: in international law, the jurisdiction to decide, in principle, that a violation of an international engagement had taken place was distinct from the jurisdiction to determine the nature and extent of reparation in general and the amount of a pecuniary indemnity in particular. ${ }^{29}$ The magistrates finally decided that the Polish government was under an obligation to pay a reparation corresponding to the damage sustained by the companies. The quantification of this compensation was to be determined in a future judgement after a specific inquiry. ${ }^{30}$ At the same time, the Court rejected the German requests of indicating provisional measures of interim protection for the payment of thirty million marks within one month. ${ }^{31}$ Only the direct agreement between the parties, on November 12, 1928, permitted the magistrates to declare that the dispute had no further purpose. ${ }^{32}$

In those years, the Court dealt with another controversy concerning Upper Silesia, which was not of an economic nature, but was somehow a direct consequence of the German presence in local economy. After 1919, many Poles had still found it convenient to send their children to German schools in order to create opportunities for stable social position in a region where economy was firmly in the hands of the German entrepreneurial class. The paradoxical effect of this attitude was that the majority attempted to pass itself off as belonging to the minority. On the other side, the Polish authorities paid great attention to the cultural and linguistic framework of the region

${ }_{27}$ Case concerning certain German interests in Polish Upper Silesia (Judgement, May 25, 1926), cit., pars. 189, 195, 199, 202, 223, 247.

${ }^{28}$ Ibidem, pars. 303-323.

${ }^{29}$ Case Concerning the Factory at Chorzów, cit. par. 106.

${ }^{30}$ The Factory at Chorzow (Order, September 13, 1928), Publications of the Permanent Court of International Justice, series A, 17, Leyden 1928.

${ }^{31}$ Case Concerning the Factory at Chorzów (Order, November 21, 1928), Publications of the Permanent Court of International Justice, series A, 12, Leyden 1928.

32 Case Concerning the Factory at Chorzow (Order, December 15, 1928), Publications of the Permanent Court of International Justice, Series A, 18/19, Leyden 1929. 
aiming to its de-Germanization, and schools consequently became a tool in the hands of respective nationalisms. ${ }^{33}$

In 1926, the Silesian administration carried out an enquiry questioning the authenticity of applications for admission to the minority schools. As a result of these investigations, 7,114 entries of children in the registers of minority schools were on various grounds invalidated: because their parents and guardians did not appear at the enquiry during the summer of 1926 or because the authorities themselves decided that the children did not belong to the German minority.

The case was discussed by the Council of the League on December 8, 1927, when Stresemann announced his intention to draw the attention of the Permanent Court of Justice. The Council first shared Polish criterion of objectivity, then proposed a compromise and decided to call a commission of pedagogues to verify the language skills of the applicants. This examination on the spot worked satisfactorily for one year. Then, Germany decided to bring the question before the Court, which supported the German thesis of the subjective value of the declarations and decided that the question whether a person did belong to a racial, linguistic or religious minority, was subjected to no verification, dispute, pressure or hindrance whatever on the part of the authorities. ${ }^{34}$

Four judges dissented from this judgement, which in any case was adaptable only to 1926-1927 and 1927-28 scholastic years, and the dispute continued through interminable debates in the Council, which in 1931 asked the Court for an advisory opinion. This act finally established that the children who had been excluded from German minority schools on the basis of the language tests could not, by reason of this circumstance, be refused access to these schools. ${ }^{35}$

The end of the twenties, as proved by the protracted scholastic question in Upper Silesia, marked a shift in German foreign policy, which became very aggressive. As suggested by Carole Fink, once its apprenticeship in the League had come to an end, Germany was ready to launch a new offensive against Poland, and in that context the German-Polish dispute became the gravest minority dispute in the League of Nations. ${ }^{36}$ Though under Marshal Piłsudski's regime many diplomatic documents noted evident improvements, the Polish authorities were repeatedly accused of infringing the provisions of the Geneva Convention, and in the Council of December 1928, Ksawery Zalewski accused of treason Otto von Ulitz and the German Verbund. Stresemann replied angrily, announcing that he intended to raise the entire problem

${ }^{33}$ Note of Mr. Leeper to Mr. Mac Donald (Warsaw, October 22, 1924), Documents on British Foreign Policy, First Series, XXV, doc. 409.

${ }^{34}$ Rights of Minorities in Upper Silesia (Judgement, April 26, 1928), Publications of the Permanent Court of International Justice, series A, 15, Leyden 1928.

35 Access to German Minority Schools in Upper Silesia (Advisory Opinion, May 15, 1931), Publications of the Permanent Court of International Justice, series A/B, 40, Leyden 1931.

${ }^{36}$ C. Fink, "Germany and the Polish Elections of November 1930: A Study of Nations Diplomacy," East European Quarterly 1981, pp. 181-207; idem, "Minority Rights as an International Question," p. 393. 
of the League's minority guarantee at the next session. ${ }^{37}$ Stresemann's successors, Julius Curtius and Heinrich Brüning, continued his aggressive minority policy against Poland, and the tensions reached the climax during the 1930 elections.

\section{CITIZENSHIP}

The protection of minorities and the agrarian reform in particular were deeply intertwined with the question of citizenship. The treaties provided all the inhabitants of a State the right of acquiring ipso facto (without any formal requirement) citizenship, except for the German colonists who settled in Polish territories after 1913. At the same time, the States were called to assure all their citizens the same rights in law and in fact. As a consequence, in order to develop agrarian and economic measures according to the interests of the majority, an option for the authorities was to make a distinction between nationals and foreigners.

The question of citizenship was first brought to the attention of the League of Nations by the German League for the Protection of the Rights of Minorities, on November 8, 1921. The Council appointed a committee, obtained supplementary information from the Polish delegates and finally approved a report on May 17, 1922. In 1923, the Secretary-General of the League submitted to the Court a request for an advisory opinion. As to the question of citizenship, the problem lay behind the contradiction between the international stipulation and its Polish application. The Polish government maintained that when the treaty granted Polish citizenship to persons of German, Austrian, Hungarian or Russian nationality, the meaning was that, among the individuals of German origin born in this territory, only some could obtain Polish citizenship: those whose parents were habitually resident there both on the day of the coming into force of the minority treaty (January 10, 1920) and on the day of the birth of the individual..$^{38}$ The Court on the contrary concluded that such an assertion was in contradiction with the treaties and was supported neither by precedents nor by international practice. To require in addition, that the parents should have renewed or preserved their habitual residence at the time when the treaty came into force could not affect the individuals whose nationality was to be determined. ${ }^{39}$

Further disputes over rights of citizenship continued to condition the relationships between Germany and Poland, and a new resolution of the Council (March 14, 1924) paved the way to establish direct negotiations. Finally, after many discussions and reciprocal accusations, Poland and Germany negotiated the Convention of Vienna (Au-

${ }^{37}$ See for example: Letter from Sir A.Chamberain to Sir. W. Erskine, Foreign Office, January 1, 1929. Note by mr. Ross to Sir. W. Erskine, Katowice December 21, 1928. Documents on British Foreign Policy, Series Ia Vol.VI, London 1975 docs. 17, 42.

${ }_{38}$ Question Concerning the Acquisition of Polish Nationality (Advisory Opinion, September 15, 1923), par. 33. Publications of the Permanent Court of International Justice, series B, 7, Leyden 1923.

${ }^{39}$ Ibidem, par. 52. 
gust 30, 1924), under the chairmanship of Prof. Georges Kaeckenbeeck, the president of the Upper Silesian Tribunal. The Convention of Vienna granted ipso facto citizenship if habitual residence dated back at least from January 1, 1908 to January 10, 1920 (art. 6, par. 1), while habitually resident German nationals needed a special authorisation (art. 7, par. 1). Ipso facto citizenship was limited only to those whose parents were habitually resident at the time of birth. Citizenship was denied in case both parents established habitual residence after January 1, 1908 or left the territory after January 10, 1920 in circumstances indicating the intention to emigrate (art. 7, par 2).$^{40}$ Both governments agreed on the eviction of 28,000-30,000 Germans and of 5,000 Poles who had respectively opted for German (Optanten) or Polish (Optanci) citizenship. A new agreement for the remaining cases of contested citizenship was signed in December 1926, but on February 25, 1929, some German deputies of the Sejm sent another petition to the League against the denial of citizenship and subsequent liquidations. ${ }^{41}$

In the late twenties, Germany and Poland were in a phase of violent disputation that was perfectly mirrored by the lively exchange of views between German and Polish delegates during the Council meeting at Lugano, in 1928, and during the 1929 summer sessions. As underlined by Henryk Chałupczak, Poland even tried to neutralize the petitioning campaign of Germany by a reciprocal petition offensive, but the asymmetry of the international system and the influence of Germany in the Council made this defensive strategy substantially fruitless ${ }^{42}$ In 1929 , Germany for the first time invoked the guarantee clause of Polish minority treaty (art. 12, p. 2) and brought a petition directly to the Council, without the preliminary study of a committee. In that period, Poland demanded the extension of minority clauses to all members of the League and, when Paris forced Warsaw to withdraw this request, the Polish government reacted to a state of renewed isolation intensifying the liquidation proceedings against German landowners and arresting the leader of the Volksbund, von Ulitz.

Stresemann expressed his concern about the new confiscations, while the Polish delegates responded that the liquidations concerned solely and exclusively German citizens, not those who acquired Polish nationality. The Council, therefore, decided to consult both parties and suggested them to negotiate in order to discover a common ground. ${ }^{43}$ The meetings began at Paris and continued in Geneva, during July and August. On August 30, an agreement was achieved: in 112 cases citizenship was conceded and the liquidation suspended. A special procedure with 2 technical delegates on each side was established to re-examine the cases yet undecided. ${ }^{44}$ Other arrangements were concluded on October 31, 1929, with the creation of an arbitral tribunal for the settlement of the disputes, and a new liquidation agreement was signed in

40 Akers-Douglas to Mac Donald (Vienna, September 3, 1924). Documents on British Foreign Policy, First Series, XXV, doc. 405. See also the report by Souza Dantas, the Brazilian member of the Committee of Three. Haln, League of Nations Secretariat, 41, 1661, 1688.

${ }^{41}$ C. Raitz von Frentz, A Lesson Forgotten, pp. 130-140.

${ }^{42}$ H. Chałupczak, "Poland's strategy to neutralize the German Minority's Petitions," pp. 16-26.

${ }^{43}$ Ojln 1929, vol. 7, pp.1017-1020.

${ }^{44}$ Ojln 1929, vol. 11, p. 1474. 
1930. The measures of complete liquidation of Germans of doubtful civil status were suspended..$^{45}$ On December 1, 1931, the mixed tribunal of German-Polish arbitrage ended its works: among the different controversies, Poland was satisfied in the Bauernbank affair of Danzig, but renounced the right of buying German farms after the death of their owners. ${ }^{46}$

In this period, Germany intensified its aggressive campaign and frequently placed minority questions directly on the agenda of the Council, for example in the case of the elections in Poznań and Pomorze, and in 1932, after three new petitions accusing the Polish authorities of subjecting the medium and small estates of the minority to the agrarian reform, while sparing large Polish estates. According to the German government, "the situation of the German minority was manifestly worse than the minorities Committee might have gathered in the past year from the information with which the Polish Government had furnished it." 47

The last controversy put under the attention of the Court, in 1933, concerned the appeal against the decisions of the Polish Taxation office affecting the administration of Prince Von Pless in the matter of income taxes for the fiscal years 1925-1930. Once again, the Court dismissed the preliminary objection concerning jurisdiction, fixed the term of February 1934 for the parts to present their documents and finally rejected the German request of fixing ad interim measures against Poland..$^{48}$

Johann Heinrich von Hochberg (Prince of Pless) was a Silesian magnate, owner of lands and coal mines and a financial supporter of German nationalist organizations. In the mid-twenties, the Prince had begun a legal controversy against the Polish Treasury and railway administration, submitting several petitions to the League and commissioning a professor of law to write legal opinions on his behalf. Besides economic aspects, the dispute also concerned the employment of German or Polish labor in the large industries of the region and was once again settled through an agreement between Berlin and Warsaw, which initially permitted the Court to put an end to the procedure on December 2, 1933, together with other pending controversies. This compromise, however, was short-lived and in August 1934, the Prince of Pless conglomerate was sequestrated. ${ }^{49}$

In this context, under the direction of Minister for Foreign Affairs Colonel Józef Beck, Poland became the first State to reach an understanding with Nazi Germany,

45 J.C. Hes se, "National Minorities in Europe: VII. The Germans in Poland," The Slavonic and East European Review 1937, vol. 16, no. 46, p. 98.

46 Note from Erskine to A. Henderson, Warsaw, November 4, 1929. Documents on British Foreign Policy, 1919-1939, series Ia, VII, London, Her Majesty's Stationery Office, 1975, doc. 48.

${ }^{47}$ Ojln 1932, vol. 7, p. 1240.

${ }^{48}$ Case concerning the Administration of the Prince Von Pless (Preliminary Objection). Publications of the Permanent Court of International Justice, Series A/B, 52, Leyden 1933. For the texts of Prince von Pless' petition and other petitions, Haln, League of Nations Secretariat, 41, 2162, 5516. Case concerning the Administration of the Prince Von Pless (Interim Measures of Protection), Publications of the Permanent Court of International Justice, Series A/B, 54, Leyden 1933.

${ }^{49}$ Case concerning the Polish Agrarian Reform and the German Minority, Publications of the Permanent Court of International Justice, series A/B, 60, Leyden 1933. C. Raitz von Frentz, A Lesson Forgotten, p. 248. 
balancing the traditional alliance with France with a surprising rapprochement. ${ }^{50} \mathrm{Af}-$ ter many years of great tensions, the non-aggression pact (January 26, 1934) bound the German and Polish governments to respect their frontiers for ten years and to reach direct understanding on questions of any nature whatsoever, including the minority issues. ${ }^{51}$

As proved by the confiscation of Prince of Pless properties, the 1934 pact was interpreted by the Polish authorities as Hitler's consent to freely deal with German minorities, and in fact it meant the consequential temporary abandonment of the defence of German minority rights, which took second line in the diplomatic correspondence..$^{52}$ But the German-Polish pact had another important consequence, as the German withdrawal from the League undermined the League's moral force. German and Polish aim was to prove that only direct negotiations could deprive the minority question of any conceivable acrimony, and that "the guarantee of the League of Nations for the protection of minorities was in fact worthless." ${ }^{53}$ In September 1934, Poland suspended article 12 of the Polish minority treaty and the whole system began its declining phase. In July 1937, the Geneva Convention expired: it was replaced by the German-Polish Minority Declaration of November 5, 1937, which finally meant the end of any form of international supervision.

\section{CONCLUSION. INTERNATIONAL JURISDICTION AND MINORITY PROTECTION}

The League of Nations represented the first historical attempt to regulate the ius ad bellum and the entire international society. But the success or failure of this

${ }^{50}$ Note from the Minister in Poland to the Foreign ministry, Warsaw, March 30, 1934. Documents on German Foreign Policy, 1918-1945, series C, II, London: Her Majesty's Stationery Office, 1958, doc. 372. See Deklaracja polsko-niemiecka o niestosowaniu przemocy z dnia 26 stycznia 1934 r. z perspektywy Polski i Europy w siedemdziesiąta rocznice podpisania, ed. M. Woj ci ec how ski, Toruń 2005; P.S. Wandycz, "The Second Republic, 1921-1939," The Polish Review 2009, vol. 54, no. 2, pp. 159-171; A.M. Cienciala, "The Foreign Policy of Józef Piłsudski and Józef Beck, 1926-1939: Misconceptions and Interpretations," The Polish Review 2011, vol. 56, no. 1/2, pp. 111-151.

${ }^{51}$ Declaration of Non-aggression and Understanding between Germany and Poland. Documents on German Foreign Policy, 1918-1945, series C, II, London, Her Majesty's Stationery Office 1958, doc. 219.

52 A. Komjathy, R. Stockwe11, German Minorities and the Third Reich: Ethnic Germans of East Central Europe between the Wars, New York-London 1980, p. 20. In 1935 and 1936 the reference to German minority in Poland in German diplomatic documents diminished. Documents on German Foreign Policy, 1918-1945, series C, IV, London, Her Majesty's Stationery Office, 1962.

${ }_{53}$ Note of the State Secretary to the embassies in Great Britain, France, Italy and Soviet Union and the legation in Poland, Berlin, September 15, 1934. Documents on German Foreign Policy, 1918-1945, series C, III, London, Her Majesty's Stationery Office, 1959. Letter of the Minister for Foreign Affairs to the ambassador in Poland, Berlin, November 14, 1934, Documents on German Foreign Policy, 1918 1945, series C, II, London, Her Majesty’s Stationery Office 1958. 
mechanism depended on the willingness of the States to use it, and the League, as Zara Steiner pointed out, was "an experiment in internationalism at a time when the counterclaims of nationalism were running powerfully in the opposite direction." 54 This was clearly true in the case of the German minority in Poland, trapped between a revanchist Berlin and an unyielding Warsaw. The German governments adopted what Chu defined as an etatist thinking, and manipulated the German minorities aiming to territorial revisionism. This "intractable fundamentalism" aggravated German minorities' status, for neither the incentives of the German government nor the diplomatic action could successfully contrast their low birth-rate and the loss of the previous economic status. On the contrary, German aggressiveness contributed to strengthen the Polish vision of a disloyal minority aiming to separatism. ${ }^{55}$

The League interfered as little as possible, either because of its internal frailty either of the enormous economic, social and political problems of Eastern Europe. To a greater extent, the impasse reflected the victors' overall failure to provide meaningful political and economic support and to institute a system of collective security and disarmament. The League was not a superstate and could only resort to boycott or menace an all-against-one conflict. But this unanimity was not present in a context that was deeply conditioned by the division between revisionist and anti-revisionist States. The League's foray into minority rights, in particular, pleased no one. On the one side, the unwilling and "unexperienced" signatories openly criticized Great Powers' paternalism and repeatedly asked for a generalization of the minority regime. ${ }^{56}$ On the other, the minorities were dissatisfied with the excess of mediation, which they considered as a weakness of the League.

The minority system was an essentially conciliatory procedure, involving the Secretariat and the Council. The disputes were only rarely referred to the Permanent Court of Justice. In these cases, the World Court tried to avoid the inflamed conflicts between the parties by applying a method of strict legal analysis and teleological interpretation. Under this viewpoint, as remarked by prof. De Azcárate (president of the Minorities Section of the League), the Court partially absorbed the aggressive polemics from the various parties of the disputes. ${ }^{57}$ At the same time, the documents regarding the German-Polish relations proved that a judicial approach could only serve as a sort of technical advice, being the concrete settlement of disputes in the hands of respective governments: the international institutions could not impose

${ }_{54}$ Z.S. Steiner, The Lights that Failed: European International History, 1919-1933, Oxford 2005, pp. 299, 349, 514 .

${ }^{55}$ P. Olstowski, "Separatyzm, dzielnicowość i unifikacja w II Rzeczypospolitej (1918-1939). Problemy integracji państwa i społeczeństwa po odzyskaniu niepodległości," Prace Historyczne 2020, vol. 147 (4), pp. 733-743. P.D. Stachura, Poland, 1918-1945, p. 82; N. Davies, God's Playground. A History of Poland, vol. II, Oxford 2005, pp. $289 \mathrm{ff}$.

${ }^{56}$ J. Kunz, "The Present Status of the International Law for the Protection of Minorities," American Journal of International Law 1954, vol. 48, pp. 282-287; C. Fink, "Minority Rights as an International Question,”p. 390.

${ }^{57}$ P. De Azcárate, League of Nations and National Minorities: An Experiment, Washington 1945, pp.130-232. G. Motta, Less than Nations. Central-Eastern European Minorities after WW1, vol. 1, Newcastle 2013, pp. 281-283. 
solutions handed down from on high. As a matter of fact, the decisions of the Court were always followed by a set of bilateral contacts to negotiate an agreement for the single controversies.

The analysis of German-Polish disputes is very significant when contextualized in the overall development process of international politics and justice. The Chorzów factory case, for example, combined political considerations and legal aspects. On the one side, it represented an attempt of accommodating Germany in a moment when Germany had a slice of legal and political goodwill. On the other, in legal terms, it strengthened the interpretation about the jurisdiction of international law and prompted international jurists to ponder upon the concept of state responsibility. ${ }^{58}$

As well explained in the publications of institutions such as the Royal Institute of International Affairs, American Society of International Law, Académie de droit international de La Haye, or the Institut de Droit International, judicial pronouncements were part of a broader process of legal development that the Court greatly contributed to lead, explaining and interpreting the principles of the treaties. In the German-Polish dispute, in particular, the Court defined the important distinction between equality in law and in fact and clarified many other concepts such as the general rule excluding private persons from appearing before the Court (ratione personarum), the incidental role of private law in the application of international law, or the problems regarding the acquisition and loss of territorial sovereignty. In the field of minority protection, the Court established that protection provided for could extend not only to nationals possessing the citizenship of the State, but also to minority residents, as an apparently equal treatment was not always sufficient to comply with the minority provisions. Finally, in 1934, it was recognised that in the case of new agreements at variance with the original treaty, such agreements may be regarded as binding the States inter se. ${ }^{59}$

This important role was unanimously recognized by distinguished jurists such as Manley Hudson, Antonio S. de Bustamante, Dionisio Anzilotti and Michał Rostworowski (all judges of the Court), and by numerous important legal experts such as Hans Kelsen. Kelsen considered assigning the chief role in settling disputes to the Council rather than to the Court, without establishing a compulsory international jurisdiction for all conflicts, to be the greatest mistake of the Versailles system. ${ }^{60}$ This decision, as prof. Kazimierz Grzybowski, from the University of Lviv, underlined in 1941, had important consequences on the international tribunal: it was termed a court; it acted as a court; and it was generally understood to be a novelty bringing a permanent factor into international relations. But the lack of an institutional

${ }^{58}$ A. Baruah, "Case Analysis on Chorzów Factory Case (Germany v. Poland)," Commonwealth Law Review Journal 2017, vol. 3, pp. 37-41.

${ }_{59} \AA$. Hammarskjöld, Juridiction internationale. Précédé d'une étude sur l'auteur, Leiden 1938; idem, "The Permanent Court of International Justice and the Development of International Law," International Affairs 1935, vol. 14 (6), pp. 797-817. See also J. Basedevant, "Regles du Droit de la Paix," Recueil Des Cours/Collected Courses 1936, 58, IV, pp. 485-500.

${ }^{60}$ H. Kelsen, "International Peace-By Court or Government?," American Journal of Sociology 1941, vol. 46, no. 4, pp. 571-581. See also A.S. de Bustamante, La Cour permanente de Justice internationale, Paris 1925; M.O. Hudson, The Permanent Court of International Justice: A Treatise, New York 1934. 
jurisdiction, the political nature of many disputes and the adjustments that interested the Court composition and statute, frequently mitigated its judicial approach, and its activity appeared more similar to arbitration than adjudication. ${ }^{61}$

The relations between the Council and the Court could even result in a conflict of competence, as the treaties formally established two distinct procedures, which did not always easily coexist. All minority questions were of a double nature, political and judicial, and the balance between these factors was essential to safeguard the integrity of the minority system. ${ }^{62}$ The interwar international system, however, emphasized the prevalence of political rather than judicial solutions, and the activity of the Court itself recognized this general approach, for example when inviting the parties to negotiate by establishing direct contacts between them.

In the German-Polish controversy, the precarious balance of legal and political methods, clearly apparent in the case of Upper Silesian schools, was finally interrupted by the 1934 pact, when both countries agreed to use bilateral mediation rather than international jurisdiction. The German-Polish dispute proved that also the judicial mechanism depended on the cohesion and peaceful coexistence within a community of States, a concept that is fundamental in international law:

the adoption of peaceful means rests upon the assumption of good faith in the relations between States. No system of international relations, however perfect, will satisfy a government whose responsible leaders consciously plan aggrandizement at the expense of neighbors. ${ }^{63}$

The German-Polish pact anticipated the successive rapid decline of international institutions. But though national antagonisms and egoisms prevailed, and condemned the League to irrelevance, in the hindsight, the activity of the Court proved that the interwar experience of internationalism achieved important results: it was this uncertain system that put idealism into international practice and decreed the entrance of the judiciary in the international arena. In fact, while the League minority system was not replied, the Court was preserved as one of the principal organs of the new international organization. Building upon the issues raised during its activity, the Court was thus reformed eliminating from its jurisdiction the cases which were really political in their nature and required to be dealt with by means of a political decision and not by reference to a court of law, as proved by the numerous Germans-Polish controversies. ${ }^{64}$

${ }^{61}$ This impression was common after 1929, when judges Fromageot and Hurst were elected, having both worked within their respective ministers of foreign affairs. O. Spiermann, International Legal Argument in the Permanent Court of Justice. The Rise of International Judiciary, New York 2004, pp. 312-314; K. Grzybowski, "Interpretation of Decisions of International Tribunals," The American Journal of International Law 1941, vol. 35, no. 3, pp. 482-495; A.K. Ku hn, "Post-War Development of International Courts," The American Journal of International Law 1943, vol. 37, no. 2, pp. 276-281.

${ }^{62}$ N. Feinberg, La juridiction de la Cour permanente de justice dans le systeme de la protection internationale des minorites, Paris 1931, pp. 133-149. See also A.J. Fockema Andreae, Important Chapter from the History of Legal Interpretation: The Jurisdiction of the First Permanent Court of International Justice (1922-1940). Leyden 1948.

${ }^{63}$ A.K. Kuhn, op. cit., p. 276.

64 "United Nations: Report of the Informal Inter-Allied Committee on the Future of the Permanent Court of International Justice," The American Journal of International Law 1945, vol. 39, no. 1, p. 17. 


\section{BIGLIOGRAPHY}

\section{Archive sources}

Historical Archives of the League of Nations (Haln, Geneva)

Secretariat, Minority Section, box 41

Official Journal of the League of Nations (Ojln)

Secretariat, Minority Section, box 41 is the folder. It is referred to the Historical Archives...

\section{Collections of documents}

Publications of the Permanent Court of International Justice, Series A, B, A./B.

Documents on German Foreign Policy, 1918-1945.

Documents on British Foreign Policy, 1919-1939.

\section{Printed sources}

Baruah A., "Case Analysis on Chorzów Factory Case (Germany v. Poland)," Commonwealth Law Review Journal 2017, vol. 3, pp. 37-41.

Basedevant J., "Regles du Droit de la Paix," Recueil Des Cours/Collected Courses 1936, 58, IV, pp. 485-500.

Bjork J.E., Neither German nor Pole: Catholicism and National Indifference in Central European Borderland, Ann Arbor 2008.

Blachetta-Madajczyk P., Klassenkampf oder Nation? Deutsche Sozialdemokratie in Polen 1918-1939, Düsseldorf 1997.

Blackbourn D., "Das Kaiserreich transnational" [in:] Das Kaiserreich transnational: Deutschland in der Welt, 1871-1914, eds. S. Conrad, J. Osterhammel, Göttingen 2004.

Błąd M., "Land Reform in the Second Polish Republic," Rural History 2000, vol. 31 (1), pp. 97-110.

Blanke R., "The German Minority in Inter-War Poland and German Foreign Policy - Some Reconsiderations," Journal of Contemporary History 1990, vol. 25, no. 1, pp. 87-102.

Blanke R., Orphans of Versailles: The Germans in Western Poland, 1918-1939, Lexington 1993.

Blanke R., "When Germans and Poles Lived Together: From the History of German-Polish Relations" [in:] Germany and Eastern Europe, Cultural Identities and Cultural Differences, eds. K. Bullivant, G. Giles, W. Pape, Amsterdam-Atlanta 1999.

Chu W., The German Minority in Interwar Poland, Cambridge 2012.

Cienciala A.M., "The Foreign Policy of Józef Piłsudski and Józef Beck, 1926-1939: Misconceptions and Interpretations," The Polish Review 2011, vol. 56, no. 1/2, pp. 111-151.

M.O. Hud s on, "The Twenty-Third Year of the Permanent Court of International Justice and Its Future," American Journal of International Law 1945, vol. 39, no. 1, pp. 1-12. 
Cienciala A.M., Komarnicki T., From Versailles to Locarno, Keys to Polish Foreign Policy 1919-1925, Lawrence, Kan. 1984.

Davies N., God's Playground: A History of Poland, vol. II, Oxford 2005.

De Azcárate P., League of Nations and National Minorities: An Experiment, Washington 1945.

De Bustamante A.S., La Cour permanente de Justice internationale, Paris 1925.

Demshuk A., The Lost German East: Forced Migration and the Politics of Memory, 19451970, New York 2012.

Dworecki Z., Problem niemiecki w świadomości narodowo-politycznej społeczeństwa polskiego województw zachodnich Rzeczypospolitej, 1922-39, Poznań 1981.

Eberhardt P., Ethnic Groups and Population Changes in Twentieth Century Central-Eastern Europe: History, Data, and Analysis, Armonk-London 2003.

Feinberg N., La juridiction de la Cour permanente de justice dans le systeme de la protection internationale des minorites, Paris 1931.

Fink C., "Defender of Minorities: Germany in the League of Nations, 1926-1933," Central European History 1972, vol. 5, pp. 330-357.

Fink C., "Germany and the Polish Elections of November 1930: A Study of Nations Diplomacy," East European Quarterly 1981, pp. 181-207.

Fink C., "Minority Rights as an International Question," Contemporary European History 2000, vol. 9, no. 3, pp. 385-400.

Fink C., "Stresemann's Minority Policies, 1924-29," Journal of Contemporary History 1979, vol. 14, no. 3, pp. 407-408.

Fockema Andrea A.J., Important Chapter from the History of Legal Interpretation: The Jurisdiction of the First Permanent Court of International Justice (1922-1940), Leyden 1948.

Grzybowski K., "Interpretation of Decisions of International Tribunals," The American Journal of International Law 1941, vol. 35, no. 3, pp. 482-495.

Gütermann C., Das Minderheitenschutzverfahren des Völkerbundes, Berlin 1979.

Hagen W., Germans, Poles, and Jews: The Nationality Conflict in the Prussian East, 17721914, Chicago 1980.

Hammarskjöld Å., Juridiction internationale. Précédé d'une étude sur l'auteur, Leiden 1938.

Hammarskjöld Å, "The Permanent Court of International Justice and the Development of International Law," International Affairs 1935, vol. 14 (6), pp. 797-817.

Healy R., "From Commonwealth to Colony? Poland under Prussia" [in:] The Shadow of Colonialism on Europeis Modern Past, eds. R. Healy, E. Dal Lago, New York 2014.

Hes se J.C., "National Minorities in Europe: VII. The Germans in Poland," The Slavonic and East European Review 1937, vol. 16, no. 46, pp. 93-101.

Hud son M.O., The Permanent Court of International Justice: A Treatise, New York 1934.

Hudson M.O., "The Twenty-Third Year of the Permanent Court of International Justice and Its Future," American Journal of International Law 1945, vol. 39, no. 1, pp. 1-12.

Hunt Tooley T., National Identity and Weimar Germany: Upper Silesia and the Eastern Border, Lincoln-London 1997.

Irredentism and Provocation: A Contribution to the History of German Minority in Poland, ed. A. Lesniewski, Poznań 1960.

Kelsen H., "International Peace-By Court or Government?," American Journal of Sociology 1941, vol. 46, no. 4, pp. 571-581.

Komjathy A., Stockwell R., German Minorities and the Third Reich: Ethnic Germans of East Central Europe between the Wars, New York-London 1980.

Krasuski J., Stosunki polsko-niemieckie 1919-1932, Poznań 1975. 
Kuhn A.K., "Post-War Development of International Courts," The American Journal of International Law 1943, vol. 37, no. 2, pp. 276-281.

Kunz J., "The Present Status of the International Law for the Protection of Minorities," American Journal of International Law 1954, vol. 48, pp. 282-287.

Lieskounig J., "Branntweintrinkende Wilde: Beyond Civilization and Outside History: The Depiction of the Poles in Gustav Freytag's 'Soll und Haben"' [in:] Germany and Eastern Europe: Cultural Identities and Cultural Differences, eds. K. Bullivant, G. Giles, W. Pape, Amsterdam-Atlanta 1999.

Ludkiewicz Z., "Land Reform in Poland," The Slavonic and East European Review 1929, vol. 8 , no. 23 , pp. 322-323.

Kamusella T., The Dynamics of the Policies of Ethnic Cleansing in Silesia in the Nineteenth and Twentieth Centuries, Budapest 1999.

Landmann T., "The Impact of Ukrainian and German Minorities in Poland on the Security of the State in the Years 1919-1939," Journal of Science of the Gen. Tadeusz Kosiuszko Military Academy of Land Forces 2016, vol. 48, no. 3, pp. 52-70.

Lundgren-Nielsen K., The Polish Problem at the Paris Peace Conference: A Study of the Policies of the Great Powers and the Poles, 1918-1919, Odense 1979.

Matelski D., Niemcy w II Rzeczypospolitej (1918-1939), 2 vols, Toruń 2018.

Matelski D., Niemcy w Polsce w XX wieku, Warszawa-Poznań 1999.

Motta G., Less than Nations. Central-Eastern European Minorities after WWI, vol. 1, Newcastle 2013.

Olstowski P., "Separatyzm, dzielnicowość i unifikacja w II Rzeczypospolitej (1918-1939). Problemy integracji państwa i społeczeństwa po odzyskaniu niepodległości," Prace Historyczne 2020, vol. 147(4), pp. 733-743.

Pronin D.T., "Land Reform in Poland, 1920-1945," Land Economics 1949, vol. 25, no. 2, pp. 133-143.

Raitz von Frentz C., A Lesson Forgotten: Minority Protection under the League of Nations: The Case of the German Minority in Poland, 1920-1934, New York 1999.

Romer E., "The Population of Poland according to the Census of 1921," Geographical Review 1923, vol. 13(3), pp. 398-412.

Roszkowski W., Landowners in Poland, 1918-1939, London 1991.

Sammartino A., The Impossible Border, Germany and the East, 1914-1922, Ithaca 2010.

Schot B., Nation oder Staat? Deutschland und der Minderheitsschutz zur Völkerbundspolitik d. Stresemann-Ära, Marburg 1988.

Schot B., Stresemann der deutsche Osten und der Völkerbund, Wiesbaden-Stuttgart 1984.

Spiermann O., International Legal Argument in the Permanent Court of Justice: The Rise of International Judiciary, New York 2004.

Spiliopoulou Åkermark A., Justifications of Minority Protection in International Law, London-the Hague-Boston 1997.

Stachura P.D., Poland 1918-1945. An Interpretative and Documentary History of the Second Republic, London-New York 2004.

Poland between the Wars, 1918-1939, ed. P.D. Stachura, London 1998.

Steiner Z.S., The Lights that Failed: European International History, 1919-1933, Oxford 2005.

Thum G., "Mythische Landschaften. Das Bild vom deutschen Osten und die Zäsuren des 20. Jahrhunderts" [in:] Traumland Osten. Deutsche Bilder vom östlichen Europa im 20. Jahrhundert, ed. G. Thum, Göttingern 2006.

Tomaszewski J., Rzeczpospolita wielu narodów, Warsaszawa, 1985.

Valdis L.O., Himmler's Auxiliaries: the Volkdeutsche Mittelstell and the German National Minorities of Europe, 1933-1945, Chapel Hill 1993. 
Wandycz P. S., "The Second Republic, 1921-1939," The Polish Review 2009, vol. 54, no. 2 , pp. 159-171.

Deklaracja polsko-niemiecka o niestosowaniu przemocy z dnia 26 stycznia 1934 r. z perspektywy Polski i Europy w siedemdziesiąta rocznice podpisania, ed. M. Wojciechowski, Torun 2005.

Wright J., Gustav Stresemann. Weimar's Greatest Statesman, New York-Oxford 2002.

Wynot E., "The Polish Germans, 1919-39," Polish Review 1972, vol. 17, pp. 23-64.

Zloch S., Polnischer Nationalismus, Politik unde Gesellschaft zwischen den beiden Weltkriegen, Koln-Weimar-Wien 2010. 